\title{
Treatment conditions and biochemical processes influencing seed priming effectiveness
}

\author{
Giuseppe Di Girolamo, Lorenzo Barbanti \\ Department of Agro-environmental Science and Technology (DiSTA), University of Bologna, Italy
}

\begin{abstract}
A review of the scientific literature indicates osmotic priming (osmopriming) as the principal method of seed priming and polyethylene glycol (PEG) as the principal osmotic agent. An analysis of the available data across experiments carried out with different species under varying conditions showed an average $11 \%$ increase in percent germination and $36 \%$ shorter mean germination time (MGT) in primed vs unprimed seeds. Moreover, in primed seeds MGT was less dependent on temperature, which is consistent with the effects expected from the treatment. Priming effects are mainly influenced by osmotic potential, temperature and time; major biochemical processes (repair of damaged DNA and RNA, preparation for cell division and increased antioxidant activity) are involved in treatment effects to an extent which is not fully ascertained in literature. A reduction of seed storage life is the major disadvantage of priming and the principal constraint to its diffusion, since dehydration to the initial moisture (drying-back) is needed to allow seed storage. Seed behaviour during drying-back, the role of the raffinose family oligosaccharides in cell membrane integrity and the expression of antioxidant enzymes in germinating seeds need to be further elucidated in a sufficient number of species, to promote a more reliable use of this technique.
\end{abstract}

\section{Introduction}

Rapid and uniform field emergence is a fundamental requisite for a good crop establishment, especially under adverse environmental conditions (Wurr and Fellows, 1983; Subedi and Ma, 2005; Gupta et $a l ., 2008)$. The time from sowing to plant establishment is a crucial period in crop growth (Bray, 1995), with a direct impact on final yield and quality (Wurr and Fellows, 1983; Gupta et al., 2008).

Techniques enhancing and stabilizing field emergence are the basis of crop success. Among them, seed priming is a pre-sowing method of improving germination, for the purpose of reducing the time from sowing to emergence, while improving emergence uniformity (Brocklehurst and Dearman, 1983). This technique involves seed hydration (usually within 10-20\% of full imbibition) (Pill, 1995), sufficient to permit pre-germinative metabolic events to proceed, but insufficient to allow radicle protrusion (Bradford, 1986). Thus, the term priming is used to describe a seed treatment devised to enhance the speed and uniformity of germination (Gupta et al., 2008).

There are three principal methods of seed priming: i) water-only treatments (hydropriming); ii) solid matrices hydrated or soaked with osmotic solutions (solid matrix priming or matri-priming) (McDonald, 2000), such as hydrated sand (Hu et al., 2005), peat and vermiculite (Taylor et al., 1998), or cotton soaked with osmotic solutions; iii) osmotic solutions (osmopriming) with polyethylene glycol (PEG) (Taylor et al., 1998; Foti et al., 2002), or inorganic salts (Alvarado et al., 1987; Haigh and Barlow, 1987; Tiryaki and Buyukcingil, 2009). The three methods may be grouped into two categories: non-controlled water uptake (hydropriming) and controlled water uptake (osmopriming, solid matrix priming and drum priming, the last a variant of hydropriming) (Taylor et al., 1998). Additional methods include seed coating with bacteria (biopriming or bio-osmopriming), e.g. Trichoderma spp. (Taylor et al., 1994; Pill et al., 2009; Begum et al., 2010) and Pseudomonas aureofaciens (Warren and Bennett, 1999). Biopriming has been able to control damping-off of seedlings in sweet corn (Zea mais L.) (Callan et al., 1990), cucumber (Cucumis melo L.) (Taylor et al., 1994; Pill et al., 2009), pea (Pisum sativum L.) (Taylor et al., 1994) and soybean (Glycine max (L.) Merr.). More to these, plant hormones may be combined with osmopriming treatments (Tiryaki and Buyukcingil, 2009).

Despite its potential benefits, seed priming has not achieved widespread circulation, as there are critical points undermining its practical use. Seed sorting is seen an interesting alternative to improve seed vigour while overcoming priming constraints (Dell'Aquila, 2009). However, the interest in seed sorting within the scientific community may not be shared by seed producers, as this technique implies selecting and discarding significant amounts of seed.

Therefore, this review is aimed at setting the state of the art on priming, focusing on treatment factors, ambient conditions and biochemical processes, to identify which aspects deserve a deeper insight in future research. 


\section{Priming effects on seeds and seedlings}

The results obtained with seed priming are heterogeneous in literature, according to species, seed quality, procedure parameters, germination conditions, etc. To ascertain the effects observed in a variety of species, we have carried out a survey of the literature since the 1980's: data of percent germination (35 cases on 18 species) and/or mean germination time (MGT; 34 cases on 18 species) with and without seed priming are reported in several scientific papers (Table 1). Osmopriming with PEG was the most frequent priming method, inducing an osmotic potential varying between $-0.5 \mathrm{MPa}$ (sweet corn, Ghiyasi et al., 2008) and -2 MPa (sunflower, Bailly et al., 2000; sugar beet, Capron et al., 2000). Treatment duration widely varied according to species and experiment, from a minimum of $8 \mathrm{~h}$ (sunflower primed in a salt solution, Wahid et al., 2008) to a maximum of 14 days (four ornamental species, Finch-Savage et al., 1991). Treatment temperature varied between $15^{\circ} \mathrm{C}$ (several cases) and $30^{\circ} \mathrm{C}$ (rice in hydropriming, Basra et al., 2005; Rudbeckia fulgida, Fay et al., 1994); most cases are comprised in the range $15-20^{\circ} \mathrm{C}$. The temperatures of seed germination also varied depending on species and aim of each experiment: sub-optimal temperatures were often adopted to better test seed response to priming.

In the 35 surveyed cases, an average germination of $71.7 \pm 23.4 \%$ and $80.3 \pm 18.2 \%$ was observed in unprimed and primed seed, respectively. Despite a difference of almost $10 \%$, data dispersion was too wide as to indicate a statistical difference between the two averages ( $t$-test). If only the gramineous species are taken into account (17 cases out of 35 ), the same pattern repeats: $78.8 \pm 21.9 \%$ and $87.5 \pm 11.5 \%$ germination in unprimed and primed seed, respectively. In both complete and reduced data set, priming restrained the variation of the cases below the average, as the lower standard deviations indicate. This in turn determined slightly higher averages.

A direct effect of temperature was not observed on percent germination of both unprimed and primed seed, which is consistent with the high inter-specific variation in thermal requirements among tested plants in the complete data set (35 cases). Conversely, a trend may be observed in the gramineous species (17 cases): in this group, the linear relation between temperature and percent germination exhibits a steeper slope in unprimed than in primed seed $(b=2.1$ and 1.1 in the two respective cases; $\mathrm{R}^{2}=0.51^{* *}$ in both). This indicates a lower dependence of primed seed on temperature to achieve a good germination, which is a proof of treatment effectiveness despite the heterogeneity among the surveyed species and priming conditions.

In the same survey (Table 1), the effect of priming on MGT appears stronger than on percent germination. MGT tended to decrease under priming, pointing to a faster germination. The high variation observed in the complete data set (average MGT $=7.6 \pm 5.0$ days in unprimed seed vs $4.9 \pm 5.2$ days in primed seed) is consistent with the high inter-specific variation among cases. The same MGT pattern repeats when monitoring only the gramineous species (data not shown).

MGT was significantly influenced by germination temperature: exponential decay functions describing MGT response to increasing temperature fit both unprimed and primed seed behaviour (Figure 1a), although in the latter case the regression was quite weaker $\left(\mathbf{R}^{2}\right.$ adj. $=0.29$ vs 0.64 ). This indicates a lower dependence of MGT of primed seed on temperature, which is consistent with the effects expected from the treatment. Likewise, the two curves tend to converge at high temperatures, indicating a lower effectiveness of priming when germination conditions improve. If only the gramineous species are monitored (12 cases out of 34 ), the two curves get closer and their regressions get tighter $\left(\mathrm{R}_{\text {adj. }}^{2}=0.89\right.$ and 0.81 in unprimed and primed seed, respectively) (Figure 1b). It is perceived, therefore, that MGT is the most relevant trait in seed germination to be influenced by priming.

\section{Triphasic model of seed imbibition}

In orthodox seeds the dry seed, ready for germination, exhibits a triphasic pattern of water uptake (Figure 2) (Bewley and Black, 1978). Phase I is the rapid water uptake that is largely a consequence of the matric forces exerted by the seed. During this phase, DNA and mitochondria are repaired and proteins are synthesized using existing messenger ribonucleic acid (mRNA) (McDonald, 2000). Phase II is a lag phase, in which seed water potential is in balance with that of the environment. In this phase the major metabolic changes preparing the embryo for germination occur, including the synthesis of mitochondria and proteins by new mRNA. Thus, phase II is also called activation phase. In phase II the germination process is completed stricto sensu; however, only in phase III the radicle emerges and the so called visible

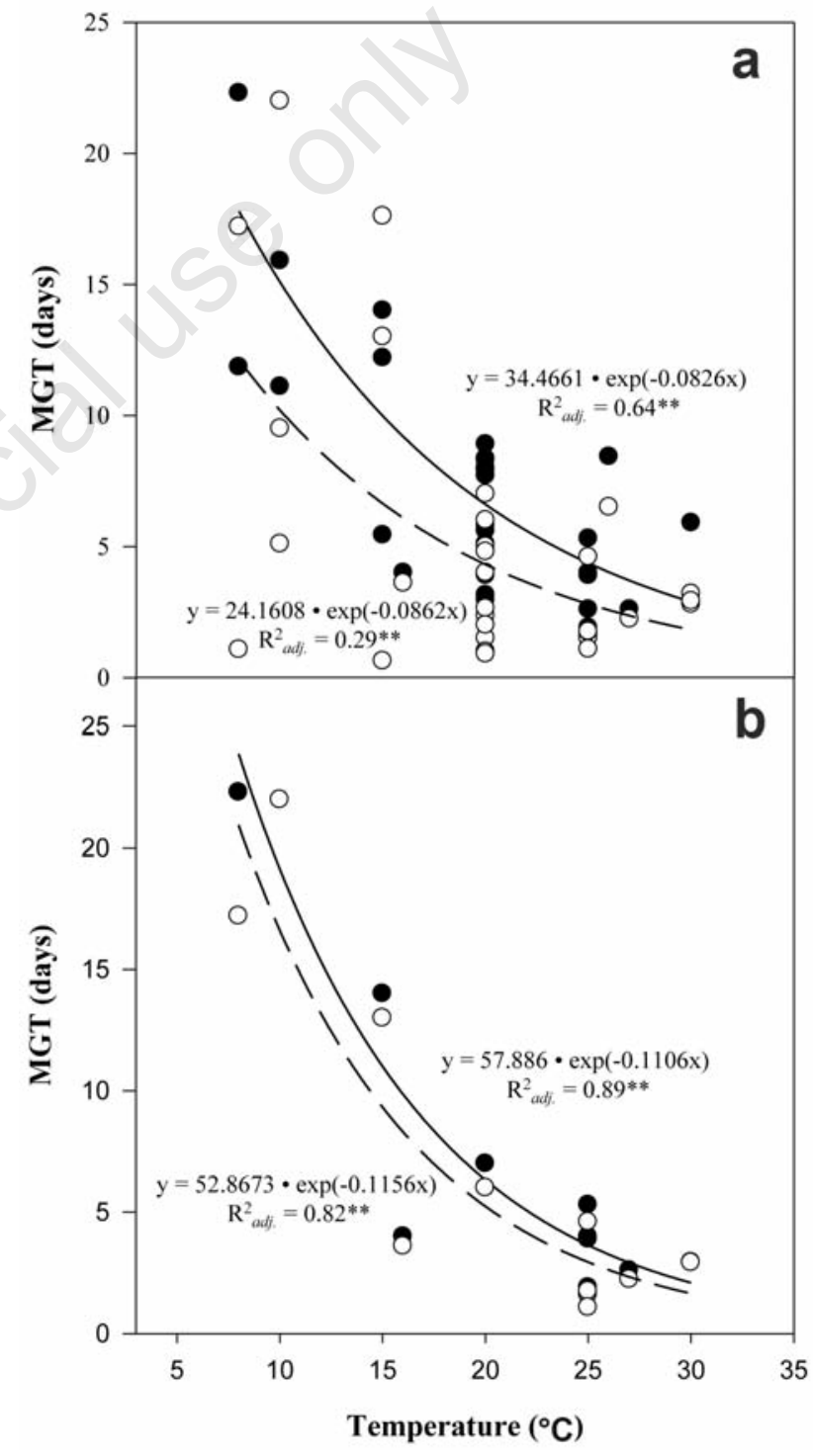

Figure 1. Relationships between temperature and mean germination time (MGT) in all the experiments reported in Table 1 (34 cases) (a), or only in the gramineous species (12 cases) (b), in unprimed (closed symbols) and primed (open symbols) seed. Exponential decay curve, unprimed (solid line) and primed (dashed line) seeds. 
Table 1. Experiments on seed priming carried out in a series of crop species, reporting data of percent germination and mean germination time.

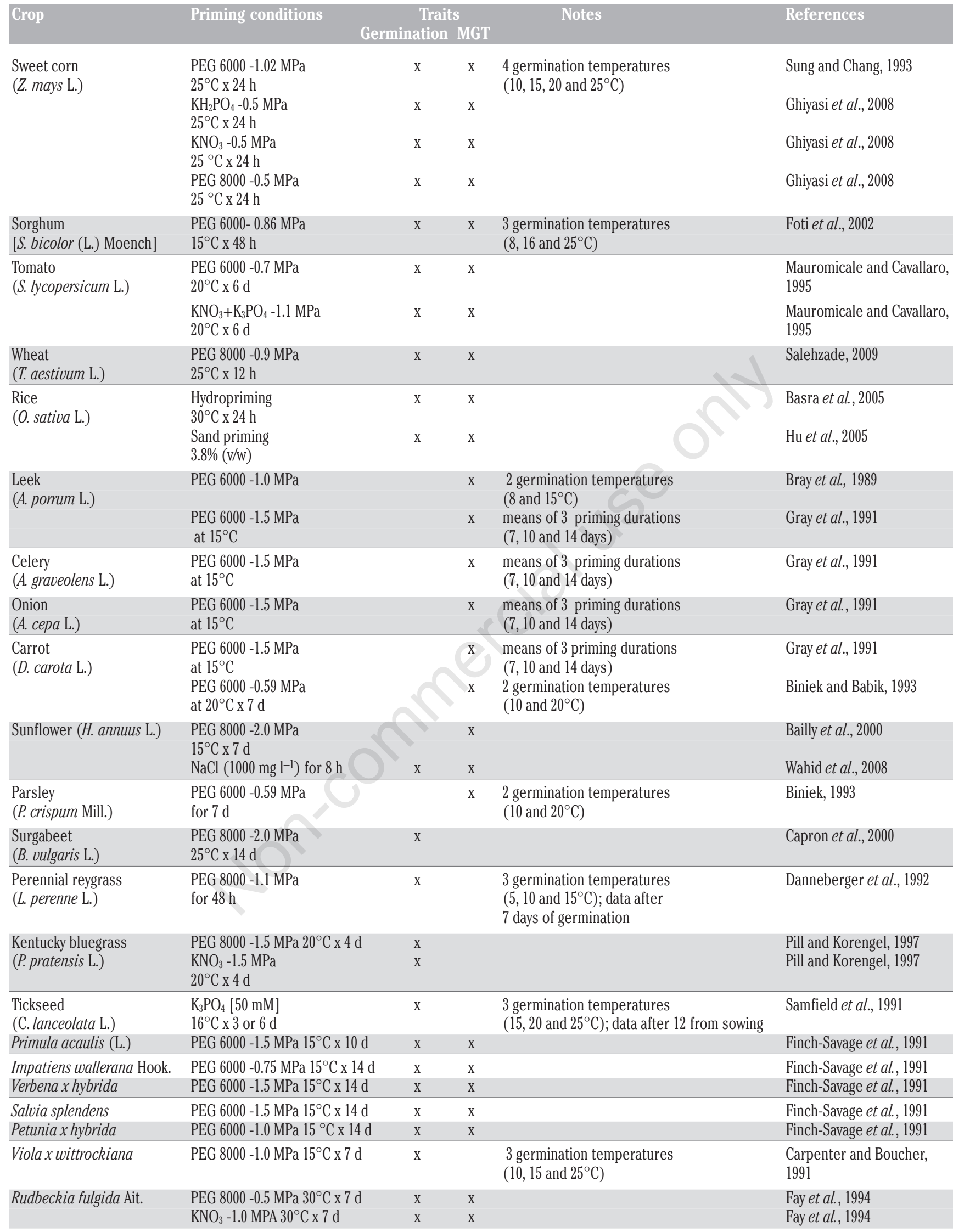

MGT, mean germination time. 
germination can be assessed (Bewley and Black, 1978; Bradford, 1995). In phase III, a second rapid uptake of water occurs. Phase I and II represent the most delicate phases for the process of germination and are crucial for a successful seed priming (Bewley, 1997).

The triphasic model has deep implications for seed viability. The seed tolerates a return to the initial moisture necessary for storage, a process know as drying-back or re-drying, when it is in phase I or II, whereas phase III is too advanced to allow a drying-back without seed damage (Taylor et al., 1998). According to the triphasic model, the start of germination is associated with a rapid synthesis of RNA and proteins, to carry out the repairing processes before the beginning of DNA replication (Osborne, 1983). Seed priming typically involves an extension of phase II, which in turn permits the completion of more repair processes (Bray, 1995), and allows the drying-back, which is necessary when the final sowing is postponed (industrial seed production). Differences in the imbibition phases of a normal germination process compared to priming followed by drying-back and subsequent germination are shown in Figure 3 (Bradford and Bewley, 2002). Under favourable conditions, the postponement of phase III involved by priming plus re-drying results in a better seed performance.

\section{Priming methods}

\section{Hydropriming}

In this method, seeds are submerged in water with or without aeration. Therefore, water is freely available to seeds, its uptake only being governed by the affinity of the seed tissue for water (Taylor et al., 1998). As a main drawback, seed germination can proceed until radicle protrusion. Thus, the process needs to be stopped at a precise moment, before phase III begins. Another disadvantage is that seeds are not equally hydrated, which results in a non-uniform activation of the physiological processes necessary to synchronize and improve germination (McDonald, 2000). A variant of hydropriming is drum priming, where seed water uptake can be regulated, overcoming the limits of hydropriming. In drum priming the seed is slowly spun in a rotating drum in which nebulized water is injected. The drum is linked to an electronic scale continuously monitoring the weight, thus the level of hydration. The process is stopped when the level of hydration set for a specific seed lot is reached (Rowse, 1996; Warren and Bennett, 1997). Drum priming consists of four stages: i) calibration necessary to determine the desired level of hydration of the seed; ii) hydration, consisting in the addition of water at different times; iii) incubation, where the seed keeps the level of hydration acquired during the priming process; iv) drying-back, where the hydrated seed is brought back to the pre-treatment moisture (Rowse, 1996). This method allows the treatment of large quantities of seed, but the most difficult step is the calibration, which is necessary to determine the right amount of water required to hydrate the seed.

\section{Solid matrix priming}

Solid matrix priming (SMP) involves the use of a wet organic or inorganic material (Parera and Cantliffe 1994), which simulates the natural imbibition processes taking place in the soil (McDonald, 2000). The substrate must possess given characteristics: low matric potential; high seed safety; high specific surface (i.e., high surface to volume ratio); negligible water solubility; high adhesiveness to seed surface; high capacity to retain water (Khan, 1991). The materials used include peat or vermiculite, or some commercial substrates such as Celite ${ }^{\circledR}$ or Micro-cel ${ }^{\circledR}$. The seed is placed on or mixed with the hydrating substrate which gradually moisturizes the seed (McDonald, 2000). In order to improve the control of imbibition, pure water may be replaced by an osmotic solution, as in osmotic priming (Khan, 1991).

\section{Osmotic priming}

Osmotic priming (osmopriming) is the process that involves the use of osmotic solutions with a low water potential to control seed water uptake. The most common substances used for osmopriming are inorganic salts, polyethylene glycol (PEG), mannitol and glycerol. The following salts are commonly used: $\mathrm{NaCl}, \mathrm{NaNO}_{3}, \mathrm{MnSO}_{4}, \mathrm{MgCl}_{2}, \mathrm{~K}_{3} \mathrm{PO}_{4}$ and $\mathrm{KNO}_{3}$ (Alvarado et al., 1987; Haigh and Barlow, 1987; Tiryaki and Buyukcingil, 2009). Some salt solution may also exert direct/indirect

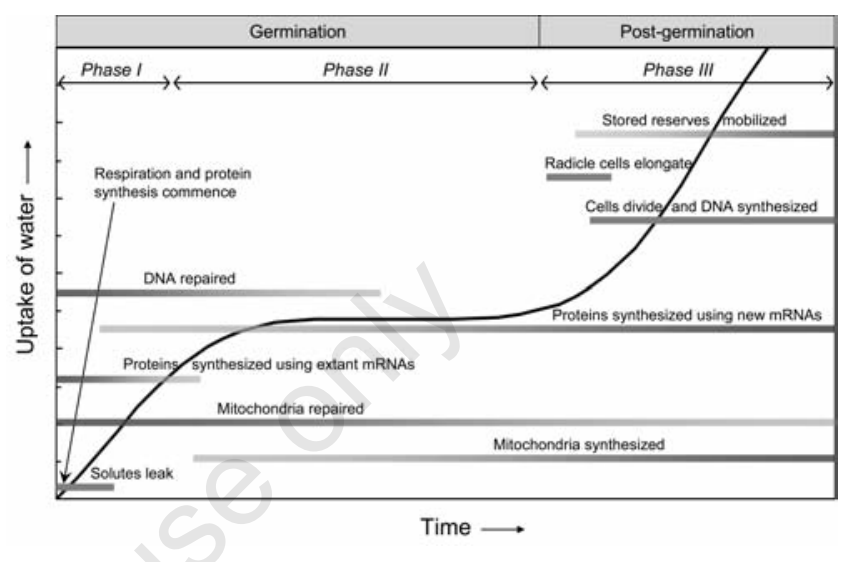

Figure 2. Events associated with germination and post-germination phases. The time for events to be completed varies from several hours to many weeks, depending on plant species, germinating conditions and seed lot quality. From: Bewley (1997), Seed germination and dormancy. Plant Cell. 9:1055-1066; www.plantcell.org. Copyright American Society of Plant Biologists.

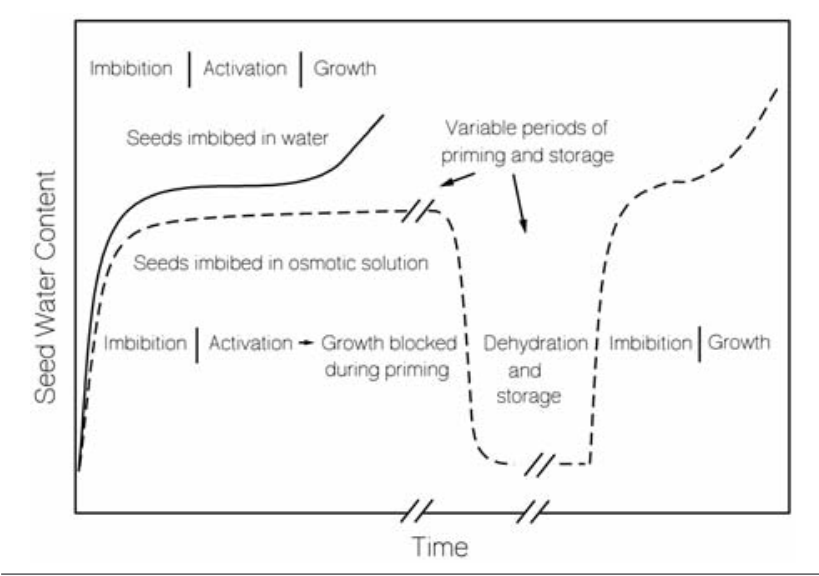

Figure 3. Time course of a standard germination process compared to a germination process including seed priming, dehydration and storage. Seed soaking in water determines a normal course of imbibition, activation and radicle protrusion (phase I, II and III of the germination process, respectively). Priming with an osmotic solution extends the activation phase (phase II) for a certain time, without leading to radicle protrusion (phase III). Seed dehydration after priming (drying-back) allows to store the seed for a variable time without losing the advantages achieved with priming. At sowing, the seed must be able to soak and develop the radicle. From: Bradford and Bewley (2002), Seeds: Biology, Technology and Role in Agriculture. In: M.J. Chrispeels and D.E. Sadava (Eds.) Plants, Genes and Crop Biotechnology, second edition. Copyright 2003, Jones \& Barlett Learning, Sudbury, MA, USA (www.jblearning.com). Reprinted with permission. 
nutritional effects, described a long time ago: Dastur and Mone (1958) observed that nitrogen, potassium and phosphate concentration in embryos of cotton seed did not change after osmopriming with such salts, whereas the concentration of some micronutrients (manganese and copper) increased. The accumulation of salts in the seed could determine toxicity (Bradford, 1995), reduce the osmotic potential and induce a high water absorption during treatment (Parera and Cantliffe, 1994), resulting in a more likely radicle protrusion.

PEG as an inert material can prevent embryo toxicity problems during priming (Cantliffe, 1983). The large size of PEG molecule (6000 to $8000 \mathrm{mw}$ ) also prevents its penetration into seed tissues, avoiding to lower the osmotic potential (Michel and Kaufman 1973; Brocklehurst and Dearman, 1984). The major disadvantage resulting from the use of PEG is the reduction of oxygen in the solution, because of its viscosity (Mexal et al., 1975); aerating the solution during PEG osmopriming can overcome this problem (Akers, 1990; Bujalski and Nienow, 1991).

Inorganic salts determine effects on germination which are different from those carried out by PEG, depending on seed species. For instance, osmopriming with inorganic salts resulted toxic to sorghum seeds (Haigh and Barlow, 1987), whereas it was as effective as PEG in asparagus (Pill, 1995) and performed better than PEG in tomato (Alvarado and Bradford, 1988; Mauromicale and Cavallaro, 1997; Ells, 1963). The difference in the response of different species to salts or PEG may be due to a selective semi-permeable layer that surrounds the embryo: when this layer is present, it allows the absorption of water, but prevents salt diffusion; when it is absent, ions can be absorbed and cause embryo damages (Welbaum et al., 1998). For example, tomato (Solanum lycopersicum L.), melon (Cucumis melo L.), lettuce (Lactuca sativa L.) and Capsicum annuum seeds possess this layer and may be safely subjected to osmopriming with inorganic salts (Welbaum and Bradford, 1990; Taylor et al., 1997). Conversely, this treatments is harmful to broccoli and cabbage seeds (Brassica oleracea L.), which lack this layer (Taylor et al., 1997).

Priming with osmotic solution involves a control of water uptake, through the adjustment of the osmotic potential $(\psi)$ (Taylor et al., 1998). The $\psi$ of an osmotic solution with inorganic salts can be calculated according to the van't Hoff equation (Salisbury and Ross, 1985):

$$
\psi=-i m R T
$$

where $i$ is the van't Hoff coefficient (adimensional), taking into account the number of molecules or ions in the solution; $m$ is the molality; im is the osmolality, i.e. the number of osmoles of solute per $\mathrm{kg}$ of solvent; $R$ is gas constant and $T$ is absolute temperature $\left({ }^{\circ} \mathrm{K}\right)$.

In a PEG 6000 solution, $\psi$ (expressed in MPa) can be calculated through the Michel and Kaufmann equation (1973):

$$
\begin{aligned}
& \psi=\left(-\left(1.18 \times 10^{-2}\right) C-\left(1.18 \times 10^{-4}\right) C^{2}+\left(2.67 \times 10^{-4}\right) C T+\right. \\
& \left.\left(8.39 \times 10^{-7}\right) C^{2} T\right)^{*} 10^{-1}
\end{aligned}
$$

where $C$ is the PEG concentration in $\mathrm{g} \mathrm{kg}^{-1}$ of $\mathrm{H}_{2} \mathrm{O}$ and $T$ is the temperature in ${ }^{\circ} \mathrm{C}$. Temperature is a important factor affecting $\psi$. For example, a PEG 6000 solution in a $250 \mathrm{~g} \mathrm{~L}^{-1}$ concentration, at $15^{\circ} \mathrm{C}$ has an osmotic potential of $-0.85 \mathrm{MPa}$; at $5^{\circ} \mathrm{C},-0.97 \mathrm{MPa}$; at $25^{\circ} \mathrm{C},-0.73 \mathrm{MPa}$. Therefore, at low temperature an osmotic solution becomes stronger than at high temperature, as $\psi$ exerts a progressively higher retention (i.e., a more negative potential).

The $\psi$ of dry orthodox seeds is very low (between -350 and -50 MPa) (Roberts and Ellis, 1989) and water uptake gradient is high when the environmental $\psi$ is between and 0 and -2 MPa (Bradford, 1995). Reducing the environmental $\psi$ slows water uptake and extends the duration of phase II, which is the aim of seed priming (Bray, 1995) (Figure 4). Tarquis and Bradford (1992) showed that the duration of phase I was similar in lettuce seed imbibed in water or in a PEG 8000
(-1.5 MPa) solution. Conversely, the duration of the lag phase was longer in the PEG solution and seed moisture grew more slowly in time. Finally, PEG-imbibed seeds did not reach phase III, in contrast to waterimbibed seeds.

Seed priming is influenced by many factors (aeration, light, temperature, time and seed quality), which are often tested in specific experiments. Aeration, especially in a PEG solution, is considered important to assist seed respiration (Bujalski et al., 1989; Bujalski and Nienow, 1991), which is essential for seed viability and contributes to synchronize the emergence (Heydecker et al., 1975). The effect of aeration, however, varies according to species: in onion, aeration of the PEG solution increased the germination percentage, compared to non-aerated treatment (Heydecker and Coolbear, 1977; Bujalski et al., 1989). By contrast, no difference was observed in the germination of lettuce between aerated and non-aerated $\mathrm{K}_{3} \mathrm{PO}_{4}$ priming (Cantliffe, 1981). In most of the reviewed cases, aerated priming is preferred, as it ensures a safer seed habitat. In small-scale experiments, the aeration is often provided by an aquarium pump (Akers and Holley, 1986).

Concerning light, the best results with lettuce were obtained with priming in the dark (Cantliffe et al., 1981), but photoblastic seeds such as lettuce and celery (Apium graveolens L.), needing light to germinate, may be illuminated during priming to reduce dormancy (Khan et al., 1978).

Temperature is another important variable, as it affects the speed of chemical reactions and $\psi$ value, according to Eq. 1 and Eq. 2 . Temperatures of about $15^{\circ} \mathrm{C}$ during priming were shown to improve the overall seed performance in most species (Bradford, 1986), whereas lower temperatures slowed the germination processes, requiring longer times to achieve the same results (McDonald, 2000). The range of temperatures normally used in priming varies between 15 and $20^{\circ} \mathrm{C}$. Treatment duration in priming mainly depends on the type of osmotic solution, osmotic potential, temperature and crop species. It also depends on the specific time and likelihood of radicle protrusion: a long priming can more easily lead to this occurrence, creating irreversible damage during drying-back (Parera and Cantliffe, 1994).

Seed quality is a key aspect influencing the effects of priming. A vigorous seed, free from pathogens is an essential requisite for a good priming result (Cantliffe et al., 1987), in contrast to the belief that this technique may improve the performance of seeds of intrinsic modest quality. Other seed characteristics may influence priming effects. For

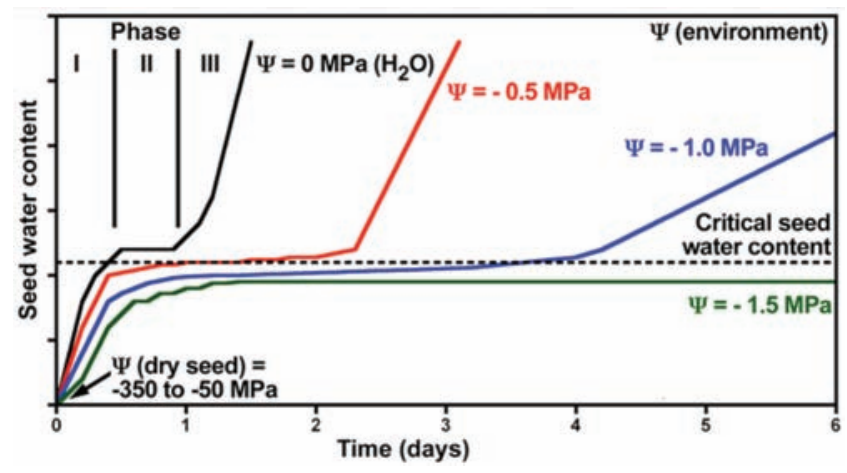

Figure 4. Influence of varying osmotic potential $(\psi)$ of a solution, on the duration of phase II (activation phase) in seed germination. By reducing $\psi$, phase II is extended and the occurrence of phase III is delayed. Copyright 2006, G. Leubner - The Seed Biology Place (www.seedbiology.de). 
instance, osmopriming with PEG solution is not suitable for seed treatment of sorghum with high content of tannin, because tannins can be removed with the solution treatment and determine a reduction of germination (Patanè et al., 2008). In fact, tannins reduce seed susceptibility to insects, birds and mould diseases and protect from weathering (McMillan et al., 1972; Harris and Burns 1973; Beta et al., 1999). In this specific case, it is advisable to adopt treatment solutions different from PEG or others technique, such as bio-priming (Patanè et al., 2008).

Another key aspect is seed maturity. Melon seeds harvested 40 days after anthesis (daa) were more responsive to osmopriming $\left(\mathrm{KNO}_{3}\right)$ than seeds harvested 60 daa (Welbaum and Bradford, 1991a). Since seeds were primed just after being harvested, it may be speculated that the physiological processes activated by the treatment contributed to complete the maturation in those seeds that had been harvested still unripe (at 40 daa). These results suggest that priming could be beneficial to standardize lots of seeds harvested at a non-uniform level of maturity. In fact, priming also enhances the vigour of immature broccoli seeds (Jett and Welbaum, 1996). Moreover, since priming melon seeds harvested at 40 daa had the same effect as after-ripening in dry storage, the treatment appeared to reduce the post-ripening dormancy (Welbaum and Bradford, 1991b).

\section{Biochemical changes induced by priming}

The positive effects of priming on the germination performance of many species are attributed to the induction of biochemical mechanisms of cell repair: the resumption of metabolic activity can restore cellular integrity, through the synthesis of nucleic acids (DNA and RNA), proteins (Bewley and Black, 1994) and the improvement of the antioxidant defence system.

\section{Effects on DNA}

Assuring DNA integrity is a factor of key importance to avoid errors of replication and synthesis of DNA. A strong increase in DNA synthesis only occurs at the end of germination (phase III) in both primed and unprimed seed, as shown in wheat seed (Dell'Aquila and Taranto, 1986). However, subsequent studies showed some effects of priming on DNA synthesis also in phase II. Leek (Allium porrum (L.) J. Gay) seed exhibited a small increase of DNA content in the embryo during this phase, because of plastid- and mitochondrial-DNA replication for the repairing processes (Osborne, 1983). Thereafter, an increase in DNA was observed 14 days after the treatment in both primed and unprimed treatment, when the seed had entered the irreversible germination phase (Bray, 1995).

It also appears that the pre-replication repair of damaged DNA favours DNA synthesis (Varier et al., 2010). A further proof of the positive effects of priming on DNA is offered by a study on Brassica oleracea L., where an aerated hydration determined an advance in DNA synthesis (Thornton et al., 1993).

In spite of its crucial role, the amount of DNA which is needed in the repair processes is only $20-30 \%$ of the total DNA synthesized during priming. The rest is mainly represented by mitochondrial DNA; in fact, the number of mitochondria was shown to rapidly increase during priming in leek seeds (Ashraf and Bray, 1993).

In addition to DNA synthesis for the repair processes and new plastids and mitochondria, in several species such as tomato (Lantieri et al., 1994; Ozbingol et al., 1999), pepper (Capsicum annuum L.) (Lantieri et al., 1993, 1994) and sugar beet (Beta vulgaris L.) (Redfearn and Osborne, 1997), a DNA synthesis for cell division was also observed. This synthesis involves the DNA fraction (4C DNA) active in the phases of synthesis $(\mathrm{S})$ and preparation for cell division $\left(\mathrm{G}_{2}\right)$ within the cell cycle.

The enhancement of DNA replication during priming depends on species, cultivar, seed lot quality (Lantieri et al., 1994) and treatment conditions (Ozbingol et al., 1999). Priming per se has no direct effect on cell division, but advances its beginning $\left(\mathrm{G}_{1}\right.$ and $\mathrm{G}_{2}$ phase of mitosis) from phase III to phase II of seed imbibition (Ozbingol et al., 1999). This advance is enabled by an accumulation of $\beta$-tubulins in primed seed, which are proteins involved in maintaining the cell cytoskeleton and forming the microtubules necessary to cell division (De Castro et al., 1995, 2000). The accumulation of tubulins is associated with the synchronization of cells on the $\mathrm{G}_{2}$ phase; in the subsequent phase III, cell division takes simultaneously place in all cells.

On the other hand, tubulins are sensitive to re-hydration, so they are not so tolerant to drying-back (Bartolo and Carter, 1991). Such circumstance may explain the drawbacks found in this procedure. This assumption is corroborated by the findings of De Castro et al. (2000), who showed that drying-back in primed tomato seed was responsible for the depolarization of the $\beta$-tubulins formed during the treatment, disabling their functions.

\section{Effects on RNA}

Osmopriming increases the RNA content in the embryo and reserve tissues of leek (Bray et al., 1989), tomato (Coolbear and Grierson, 1979) and lettuce (Khan et al., 1980). Bray et al. (1989) proved that this accumulation involved rRNA (ribosomial RNA; $85 \%$ of total RNA), in a turnover between degradation of damaged rRNA and synthesis of new rRNA, while the level of mRNA (messenger RNA; $0.5 \%$ of total RNA) remained constant. rRNA is as much necessary to repair cell damages as DNA. Priming allows the recovery of rRNA integrity (Coolbear et al., 1990), in turn ensuring a correct coding of amino acids for the synthesis of proteins during seed germination.

\section{Effects on protein synthesis}

In protein synthesis, a compensation mechanism has been elucidated. Protein synthesis, an essential requisite for germination, starts several minutes after hydration (Cheung et al., 1979). At this stage, osmopriming depresses protein synthesis in the embryo and reserve tissues, compared to seed soaked in water for the same time. Then, priming induces a higher level in the subsequent germination. In fact, Bray (1995) showed that the amount of synthesized protein observed 2 $\mathrm{d}$ after germination in primed leek seed was the same as that observed $4 \mathrm{~d}$ after germination in unprimed seed. Chen et al. (2011) observed an increase of dehydrin in spinach (Spinacia oleracea L.) during osmoprimng. This increase was also observed during germination of primed seeds in chilling stress and desiccation stress, suggesting that osmopriming may play a positive role in the tolerance to these stresses.

On the other hand, priming does not appear to induce the synthesis of specific proteins, as it has been demonstrated by the qualitative analysis of protein pattern in pea seeds (Dell'Aquila and Bewley, 1989).

\section{Effects on enzymes}

Osmopriming induces the synthesis and activation of enzymes catalyzing the breakdown and mobilization of reserve substances (Varier 
et al., 2010). This occurrence has been observed in several species. In sugar beet, for instance, the degradation product of the reserve globulin 11-S was shown to cumulate after osmopriming (Job et al., 1999). Other enzymes are activated for the mobilization of reserve carbohydrates ( $\alpha$ and $\beta$ amylases) and lipids (isocitrate liase) (Sung and Chang, 1993). This effect is associated with the water deficit induced by osmopriming, which is supposed to determine a mobilization of reserve proteins (Varier et al., 2010).

Seed deterioration during storage is another domain of enzyme activity related to priming. This deterioration is associated with the accumulation of active oxygen species (AOS), such as oxygen peroxide $\left(\mathrm{H}_{2} \mathrm{O}_{2}\right)$, superoxide anion $\left(\mathrm{O}_{2}{ }^{--}\right)$and hydroxyl radical $\left(\mathrm{OH}^{\bullet}\right)$. AOS react with most organic molecules, causing oxidation and carbonylation of amino acid residues and DNA mutation (Bailly, 2004); they also react with polyunsaturated fatty acids found in cell membranes, leading to lipid peroxidation and consequent disruption of membrane integrity (Bailly et al., 1998). In plants, the defence system includes antioxidant enzymes, i.e. scavengers of AOS such as superoxide dismutate (SOD), catalase (CAT) and glutatione reductase (GR) (Bailly et al., 1998). Priming appears to strengthen this defence system: in fact, the treatment was associated with an increase in CAT expression in Arabidopsis (Gallardo et al., 2001) and sunflower (Helianthus annuus L.) (Kibinza et al., 2011), and CAT activity in soybean (Posmyk et al., 2001) and maize seeds (Chiu et al., 2002). In sunflower seeds, Bailly et al. $(1998 ; 2000)$ showed that osmopriming with PEG led to an increase of SOD and CAT, in response to the rise of metabolic activity during priming, which is responsible for a secondary production of AOS from mitochondrial respiration and/or lipid peroxidation. It appears, therefore, that the defence system of the antioxidant enzymes is enhanced in response to a higher amount of potential threats.

Examples are offered in literature (Table 2), showing a relevant decrease of malondialdehyde (MDA), a product of lipid peroxidation: $-20 \%$ in echinacea (Echinacea purpurea L.) (Chiu et al., 2006), and $-40 \%$ in spinach (Chen and Arora, 2011). In addition to reduced MDA, also SOD, CAT and GR concentrations in echinacea were increased by priming (Table 2), in agreement with Bailly et al. (1998 and 2000). In contrast to this, spinach SOD and CAT declined (Table 2), although this species possesses alternative antioxidant mechanisms, such as the Asa-GSH cycle, an important AOS-scavenging pathway (Bailly et al., 2001; De Tullio and Arrigoni, 2003; Garnczarska and Wojtyla, 2008).

It may be concluded from all these clues that the physiological processes activated by priming, involving nucleic acids, proteins and enzymes, are devised to withstand multiple stresses and still result in a vigorous germination, thus reducing the time to emergence and promoting early plant development.

\section{Drying-back and seed longevity}

Priming is connected with practical interest in subsequent seed handling and storage. Direct seeding of primed seed is often unfeasible (e.g., wet seeds bridging within seeders), risky (e.g., rains delaying the seeding date), or unaffordable at a small farm scale. Therefore, dryingback is necessary to allow seed storage after priming and represents a crucial phase, as the benefits achieved with priming may be lost (Parera and Cantliffe, 1992). The effects of priming on seed longevity appear somewhat contradictory: the treatment was shown to enhance seed longevity in pepper (Georghiou et al., 1987), onion (Allium cepa L.) (Dearman et al., 1986) and Brussels sprouts (Burgass and Powell, 1984), whereas it was responsible for a depression of longevity in seeds of leek (A. porrum L.) (Bray, 1995), carrot (Daucus carota L.) (Dearman et al., 1987), wheat (Triticum aestivum L.) (Nath et al., 1991), lettuce (Kraak and Weges, 1989; Tarquis and Bradford, 1992) and tomato (Alvarado and Bradford, 1988; Argerich and Bradford, 1989; Owen and Pill, 1994).

However, these contrasting effects appear to depend on the conditions of drying-back and storage. A rapid drying-back may alter the content of soluble carbohydrates, in turn reducing the tolerance to desiccation and seed longevity (Gurusinghe and Bradford, 2001). Conversely, a slow drying-back may improve seed longevity after priming (Bruggink et al., 1999). Therefore, the two aspects of tolerance to desiccation and seed longevity are clearly related (Ellis and Hong, 1994; Hay and Probert, 1995).

Sugars and their derivatives play an important role in desiccation tolerance and seed longevity (Horbowicz and Obendorf, 1994; Brenac et al., 1997; Obendorf, 1997; Obendorf et al., 1998), since they are, supposedly, involved in maintaining membrane integrity (Crowe et al., 1988; Hoekstra et al., 1992; Oliver et al., 1998) and three-dimensional structure of proteins (Crowe et al., 1992; Wolkers et al., 1998) during dryingback. The sugars playing this role are sucrose and some raffinose family oligosaccharides (RFOs), namely raffinose, stachyose and verbascose (Obendorf, 1997). These sugars interact with the lipids and proteins of cell membrane forming glycolipids and glycoproteins, respectively. Furthermore, they form a glassy layer at the membrane level (Leprince et al., 1993), countering degradation during desiccation and storage (Gurusinghe and Bradford, 2001).

During hydration, RFOs are the first sugars to be metabolized. Their consumption during priming and a lack of accumulation during dryingback, are responsible for a reduced formation of the glassy layer, resulting in accelerated deterioration (Gurusinghe and Bradford, 2001). In support to this hypothesis, Gurusinghe and Bradford (2001) found a decreasing sucrose and raffinose concentration with increasing hydropriming duration in lettuce seed. More to this, in the same work

Table 2. Effects of priming on cell antioxidant activity in terms of malondialdehyde (MDA), superoxide dismutase (SOD), catalase (CAT) and glutathione reductase (GR) in two experiments reported in literature.

\begin{tabular}{|c|c|c|c|c|c|c|}
\hline Species & Treatment & $\begin{array}{c}\text { MDA } \\
\text { nmol g }^{-1}\end{array}$ & $\begin{array}{l}\text { SOD } \\
\text { Unit }^{\circ}\end{array}$ & $\begin{array}{c}\text { CAT } \\
\text { Unit }^{\#}\end{array}$ & $\begin{array}{c}\text { GR } \\
\text { Unit }^{\#}\end{array}$ & References \\
\hline \multirow[t]{2}{*}{ Echinacea purpurea L. } & Control & $17.0^{*}$ & $13.3^{*}$ & $11.8^{*}$ & $5.1^{*}$ & \multirow[t]{2}{*}{ Chiu et al., 2006} \\
\hline & Primed ${ }^{\S}$ & $13.4^{*}$ & $27.8^{*}$ & $15.6^{*}$ & $9.1^{*}$ & \\
\hline Spinacia oleracea L. & $\begin{array}{l}\text { Control } \\
\text { Primed }^{\wedge}\end{array}$ & $\begin{array}{l}4.1 \\
1.7\end{array}$ & $\begin{array}{l}0.9 \\
0.5\end{array}$ & $\begin{array}{c}0.1 \\
0.04\end{array}$ & $\begin{array}{l}- \\
-\end{array}$ & Chen and Arora, 2011 \\
\hline
\end{tabular}

${ }^{\circ}$ The SOD activity was expressed as: i) the amount of enzyme needed to inhibit the reaction by half per seed per minute, in $E$. purpurea; ii) the amount of enzyme needed to reach $50 \%$ inhibition of the reaction in the "minus enzyme extract" control, in $S$. oleracea. "One unit represents: i) $1 \mathrm{~mol}$ of substrate undergoing reaction per mg protein per minute, in E. purpurea; ii) the degradation of $1 \mu \mathrm{M} \mathrm{H}_{2} \mathrm{O}_{2}$ in 1 minute, in $S$. oleracea. §Primed in non-aerated solution of PEG $6000(-0.5 \mathrm{MPa})$ at $25^{\circ} \mathrm{C}$ x 6 days. ${ }^{\wedge}$ Primed in solution of PEG $8000(-0.6 \mathrm{MPa})$ at $15^{\circ} \mathrm{C}$ x 4 days. *Average values of large- and small-size seeds (thousand-seed weight, $5.31 \pm 0.24$ $\mathrm{g}$ and $4.42 \pm 0.21 \mathrm{~g}$, respectively). 
the p50 value, a longevity index representing the number of days of ageing needed to reduce seed viability by $50 \%$, was directly related to the concentration of sucrose and raffinose, meaning a better longevity at a higher content of such sugars.

In addition to sugars, proteins may act to increase the desiccation tolerance during drying-back. In seeds of Brassica oleracea, a slow drying-back was associated with an increased expression of two genes of stress tolerance (Soeda et al., 2005). These genes, Em6 and RAB 18, encode proteins belonging to the LEA (Late Embryogenesis Abundant) group, induced by various stresses and conferring desiccation tolerance during seed maturation. Em6 and $R A B 18$ were expressed to a lesser extent in a rapid drying-back (Soeda et al., 2005). In tomato, a post-priming treatment allowing a gradual reduction of seed moisture (incubation at 30 or $40^{\circ} \mathrm{C}$ for $2-4 \mathrm{~h}$ ) proved a sound way to restore longevity (Gurusinghe and Bradford, 2001; Gurusinghe et al., 2002). This treatment was accompanied by an increase in BiP proteins (Immunoglobulin Binding Protein), another group contributing to restore the functions of proteins damaged by the processes of seed wetting and drying (Gurusinghe et al., 2002).

\section{Conclusions}

Priming allows the synchronization of the metabolic events in a seed lot, improving the speed and uniformity of field emergence. During the treatment, seed damage due to various metabolic and genetic events may be repaired through the completion of phase I and II of seed imbibition.

Optimal priming ensures a flawless replication and transcription of nucleic acids, promotes the activation of enzymes mobilizing reserve proteins, and prepares the cells for division. A major drawback is that seed longevity is endangered by priming, although this depends on the conditions during drying-back; a slow drying-back counters the deteriorating processes, enabling a recovery of seed longevity after the treatment.

The adoption of priming fosters an overall increase in percent germination $(+11 \%)$ associated with a shorter mean germination time (-36\%). These simple figures demonstrate priming value in the perspective of practical utilization for commercial purposes (seed firms), but also in programmes of agricultural development where yields are constrained by poor seedling establishment.

Despite such advantages, priming has not achieved a widespread diffusion. The time course of scientific literature suggests some trends in the research on the subject, hinting at the problems that remain to be solved: of the 133 references cited in this review, only 13 date back to the 1970 s or earlier, 27 to the 1980 's, 60 to the 1990 's, 33 from the year 2000 to present. This pattern outlines an increasing, then decreasing interest in the topic, which is counterbalanced by the fact that recent research has more closely addressed the subject of biochemical changes, than the issues of priming methods, effects and seed longevity after the treatment: in fact, sub-dividing the cited references by subject, biochemical changes result the main focus in $30 \%$ of the references published in the 1980 s, $50 \%$ in the 1990 s, $55 \%$ from the year 2000 to present. Therefore, a decreasing effort in quantitative terms has been compensated by an increasing commitment to unravel the complex metabolic response to the treatment.

In conclusion, the basic mechanisms of priming are generally acknowledged, whereas the underpinning physiological processes are not always elucidated and described in a sufficient number of species. This reflects in the contrasting effects sometimes observed after priming, which are responsible for the uncertainties still surrounding this technique. It appears, therefore, that providing further clues on the subject is the only way to achieve meaningful and reliable benefits from priming. The association with other techniques of seed vigour enhancement such as seed sorting and physical treatments (polishing, coating, etc.) stands out as the ultimate approach in the quest for high and consistent seed performance.

\section{References}

Akers SW, 1990. Seed response to priming in aerated solutions. Search 19:8-17.

Akers SW, Holley KE, 1986. SPS: a system for priming seeds using aerated polyethylene glycol or salt solution. Hortscience 21:529-531.

Alvarado AD, Bradford KJ, 1988. Priming and storage of tomato (Lycopersicon esculentum) seeds. I. Effects of storage temperature on germination rate and viability. Seed Sci. Technol. 16:601-612.

Alvarado AD, Bradford KJ, Hewitt JD, 1987. Osmotic priming of tomato seeds: effects on germination, field emergence, seedling growth, and fruit yield. J. Am. Soc. Hortic. Sci. 112:427-432.

Argerich CA, Bradford KJ, 1989. The effects of priming and ageing on seed vigour in tomato. J. Exp. Bot. 40:599-607.

Ashraf M, Bray CM, 1993. DNA synthesis in osmoprimed leek (Allium porrum L.) seed. Seed Sci. Res. 3:15-23.

Bailly C, 2004. Active oxygen species and antioxidants in seed biology. Seed Sci. Res. 14:93-107.

Bailly C, Audigier C, Ladonne F, Wagner MH, Coste F, Corbineau E, Côme D, 2001. Changes in oligosaccharide content and antioxidant enzyme activities in developing bean seeds as related to acquisition of drying tolerance and seed quality. J. Exp. Bot. 52:701-708.

Bailly C, Benamar A, Corbineau F, Côme D, 1998. Free radical scavenging as affected by accelerated ageing and subsequent priming in sunflower seeds. Physiol. Plant. 104:646-652.

Bailly C, Benamar A, Corbineau F, Côme D, 2000. Antioxidant systems in sunflower (Helianthus annuus L.) seeds as affected by priming. Seed Sci. Res. 10:35-42.

Bartolo ME, Carter JV, 1991. Microtubules in the mesophyll cells of nonacclimated and cold-acclimated spinach. Plant Physiol. 97:175-181.

Basra SMA, Farooq M, Tabassum R, Ahmed N, 2005. Physiological and biochemical aspects of pre-sowing seed treatments in fine rice (Oryza sativa L.). Seed Sci. Technol. 33:623-628.

Begum MM, Sariah M, Puteh AB, Zainal Abidin MA, Rahman MA, Siddiqui Y, 2010. Field performance of bio-primed seeds to suppress Colletotrichum truncatum causing damping-off and seedling stand of soybean. Biol. Control, 53:18-23.

Beta T, Roney LW, Marovatsanga LT, Taylor RN, 1999. Phenolic compounds and kernel characteristics of Zimbabwean sorghums. J. Sci. Food Agric. 79:1003-1110.

Bewley JD, 1997. Seed germination and dormancy. Plant Cell 9:10551066.

Bewley JD, Black M, 1978. Physiology and biochemistry of seeds in relation to germination. In: Development, germination and growth, vol. 1. Springer-Verlag, New York, NY, USA, pp 305-375.

Bewley JD, Black M, 1994. Seeds: physiology of development and germination, 2nd ed., Plenum Press, New York, NY, USA.

Biniek A, Babik I, 1993. The influence of osmoconditioning in polyethylene glycol (PEG 6000) on the germination and emergence of carrot and parsley seeds. Acta Hortic. 371:77-81.

Bradford KJ, 1986. Manipulation of seed water relations via osmotic priming to improve germination under stress conditions. Hortscience 21:1105-1112.

Bradford KJ, 1995. Water relations in seed germination. In: J. Kigel and G. Galili (eds.) Seed Development and Germination. Marcel Dekker, Inc., New York, NY, USA, pp 351-396.

Bradford KI, Bewley JD, 2002. Seeds: biology, technology and role in 
agriculture. In: M.J. Chrispeels and D.E, Sadava (eds.) Plants, genes and crop biotechnology, 2nd ed., Jones and Barlett, Boston, MA, USA, pp 210-239.

Bray CM, 1995. Biochemical processes during the osmopriming of seeds. In: J. Kigel and G. Galili (eds.) Seed development and germination. Marcel Dekker, Inc., New York, NY, USA, pp 767-789.

Bray CM, Davison PA, Ashraf M, Taylor RM, 1989. Biochemical changes during osmopriming of leek seeds. Ann. Bot. 63:185-193.

Brenac P, Horbowicz M, Downer SM, Dickerman AM, Smith ME, Oberdorf RL, 1997. Raffinose accumulation related to desiccation tolerance during maize (Zea mays L.) seed development and maturation. J. Plant Physiol. 4:481-488.

Brocklehurst PA, Dearman J, 1983. Interactions between seed priming treatments and nine seed lots of carrots, celery and onion. Ann. Appl. Biol. 102:577-584.

Brocklehurst PA, Dearman J, 1984. A comparison of different chemicals for osmotic treatments of vegetable seed. Ann. Appl. Biol. 105:391398.

Bruggink GT, Ooms JJJ, van der Toorn P, 1999. Induction of longevity in primed seeds. Seed Sci. Res. 9:49-53.

Bujalski W, Nienow AW, 1991. Large-scale osmotic priming of onion seeds: a comparison of different strategies for oxygenation. Sci. Hortic., 46:13-24.

Bujalski W, Nienow AW, Gray D, 1989. Establishing the large scale osmotic priming of onion seeds by using enriched air. Ann. Appl. Biol. 115:171-176.

Burgass RW, Powell AA, 1984. Evidence for repair processes in the invigoration of seeds by hydration. Ann. Bot. 53:753-757.

Burns RE, 1971. Methods for estimation of tannin in grain sorghum. Agron. J. 63:511-512.

Callan NW, Mathre DE, Miller JB, 1990. Bio-priming seed treatment for biological control of Pythium ultimum preemergence damping-off in sh2 sweet corn. Plant Dis. 74:368-372.

Cantliffe DJ, 1981. Priming of lettuce for early and uniform emergence under conditions of environmental stress. Acta Hortic. 122:29-38.

Cantliffe DJ, 1983. Sowing primed seed. Am. Veg. Grower. 31, 42-43.

Cantliffe DJ, Elbala M, Guedes A, Odell GB, Perkins-Veazie P, Schultheis JR, Seale DN, Shuler KD, Tanne I, Watkins JT, 1987. Improving stand establishment of direct-seeded vegetables in Florida. Proc. Florida State Horticultural Society, 100:213-216.

Cantliffe DJ, Shuler KD, Guedes AC. 1981. Overcoming seed thermodormancy in a heat sensitive romaine lettuce by seed priming. Hortscience 16:196-198.

Capron I, Corbineaua F, Dacher F, Job C, Come D, Job D, 2000. Sugarbeet seed priming: effects of priming conditions on germination, solubilization of 11-S globulin and accumulation of LEA proteins. Seed Sci. Res. 10:243-254.

Carpenter WJ, Boucher JF, 1991. Priming improves high-temperature germination of pansy seed. Hortscience 26:541-544.

Chen K, Arora R, 2011. Dynamics of the antioxidant system during seed osmopriming, post-priming germination, and seedling establishment in Spinach (Spinacia oleracea). Plant Sci. 180:212-220.

Chen K, Fessehaie A, Arora R, 2012. Dehydrin metabolism is altered during seed osmopriming and subsequent germination under chilling and desiccation in Spinacia oleracea L. cv. Bloomsdale: possible role in stress tolerance. Plant Sci. 183:27-36.

Cheung CP, Wu J, Suhadolnik RJ, 1979. Dependence of protein synthesis on RNA synthesis during the early hours of germination of wheat embryos. Nature 277:66-67.

Chiu KY, Chuang SJ, Sung JM, 2006. Both anti-oxidant and lipid-carbohydrate conversion enhancements are involved in primingimproved emergence of Echinacea purpurea seeds that differ in size. Sci. Hortic., 108:220-226.

Chiu KY, Chen CL, Sung JM, 2002. Effects of priming temperature on storability of primed sh-2 sweet corn seed. Crop Sci. 42:1996-2003.

Coolbear P, Grierson D, 1979. Studies on the changes in the major nucleic acid components of tomato seeds (Lycopersicon esculentum Mill.) resulting from presowing treatments. J. Exp. Bot. 30:1153-1162.

Coolbear P, Slater RJ, Bryant JA, 1990. Changes in nucleic acid levels associated with improved germination performance of tomato seeds after low-temperature presowing treatments. Ann. Bot. 65:187-195.

Crowe JH, Crowe LM, Carpenter JF, Rudolph AS, Wistrom CA, Spargo BJ, Anchordoguy TJ, 1988. Interactions of sugar with membranes. Biochim. Biophys. Acta 947:367-384.

Crowe JH, Hoekstra FA, Crowe LM, 1992. Anhydrobiosis. Annu. Rev. Physiol. 54:579-599.

Danneberger TK, McDonald MB, Geron CA, Kumari P, 1992. Rate of germination and seedling growth of perennial ryegrass seed following osmoconditioning. Hortscience 27:28-30.

Dastur RH, Mone LT, 1958. Scientific aspects of the method of pre-soaking seeds in solution of salts for getting increased yields of crops plants. Indian J. Agr. Sci. 28:1-12.

De Castro RD, van Lammeren AAM, Groot SPC, Bino RJ, Hilhorst HWM 2000. Cell division and subsequent radicle protrusion in tomato seeds are inhibited by osmotic stress but DNA synthesis and formation of microtubular cytoskeleton are not. Plant Physiol. 122:327-336.

De Castro RD, Zheng XY, Bergervoet JHW, De Vos CHR, Bino RJ, 1995. $\beta$-tubulin accumulation and DNA replication in imbibing tomato seeds. Plant Physiol. 109:499-504.

De Tullio MC, Arrigoni 0, 2003. The ascorbic acid system in seeds: to protect and to serve. Seed Sci. Res. 13:249-260.

Dearman J, Brocklehurst PA, Drew RLK, 1986. Effects of osmotic priming and aging on onion seed germination. Ann. Appl. Biol. 108:639648.

Dearman J, Brocklehurst PA, Drew RLK, 1987. Effects of osmotic priming and aging on the germination and emergence of carrot and leek seed. Ann. Appl. Biol. 111:717-722.

Dell'Aquila A, 2009. Development of novel techniques in conditioning, testing and sorting seed physiological quality. Seed Sci. Technol. 37:608-624.

Dell'Aquila A, Bewley JD, 1989. Protein synthesis in the axes of polyethylene glycol treated pea seeds and during subsequent germination. J. Exp. Bot. 40:1001-1007.

Dell'Aquila A, Taranto G, 1986. Cell division and DNA-synthesis during osmopriming treatment and following germination in aged wheat embryos. Seed Sci. Technol. 14:333-341.

Ellis RH, Hong TD, 1994. Desiccation tolerance and potential longevity in developing seeds of rice (Oryza sativa L.). Ann. Bot. 73:501-506.

Ells JE, 1963. The influence of treating tomato seed with nutrient solutions on emergence rate and seedling growth. Proc. American Society Horticultural Science, 83:684-687.

Fay AM, Bennet MA, Still SM, 1994. Osmotic seed priming of Rudbeckia fulgida improves germination and expands germination range. Hortscience 29: 868-870.

Finch-Savage WE, Gray D, Dickson GM, 1991. The combined effects of osmotic priming with plant growth regulator and fungicide soaks on the seed quality of five bedding plant species. Seed Sci. Technol. 19:495-503.

Foti S, Cosentino SL, Patanè C, D'Agosta GM, 2002. Effects of osmoconditioning upon seed germination of sorghum (Sorghum bicolor (L.) Moench) under low temperatures. Seed Sci. Technol. 30:521533.

Gallardo K, Job C, Groot SPC, Puype M, Demol H, Vandekerckhove J, Job D, 2001. Proteomic analysis of Arabidopsis seed germination and priming. Plant Physiol. 126:835-848. 
Garnczarska M, Wojtyla L, 2008. Ascorbate and glutathione metabolism in embryo axes and cotyledons of germinating lupine seeds. Biol. Plant. 52:681-686.

Georghiou K, Thanos CA, Passam HC, 1987. Osmoconditioning as a means of counteracting the aging of pepper seeds during hightemperature storage. Ann. Bot. 60:279-285.

Ghiyasi M, Zardoshty MR, Mogadam AF, Tajbakhsh M, Amirnia R, 2008. Effect of osmopriming on germination and seedling growth of corn (Zea mays L.) seeds. Res. J. Biol. Sci. 3:779-782.

Gray D, Drew RLK, Bujalski W, Nienow AW, 1991. Comparison of polyethylene glycol polymers, betaine and L-proline for priming vegetable seed. Seed Sci. Technol. 19:581-590.

Gupta A, Dadlani M, Arun Kumar MB, Roy M, Naseem M, Choudhary VK, Maiti RK, 2008. Seed Priming: the aftermath. Int. J. Agric. Environ. Biotechnol. 1:199-209.

Gurusinghe S, Bradford KJ, 2001. Galactosyl-sucrose oligosaccharides and potential longevity of primed seeds. Seed Sci. Res. 11:121-133.

Gurusinghe S, Powell ALT, Bradford KJ, 2002. Enhanced expression of $\mathrm{BiP}$ is associated with treatments that extend storage longevity of primed tomato seeds. J. Am. Soc. Hortic. Sci. 127:528-534.

Haigh AM, Barlow EWR, 1987. Germination and priming of tomato, carrot, onion and sorghum seeds in a range of osmotica. J. Am. Soc. Hortic. Sci. 112:202-208.

Harris HB, Burns RE, 1973. Relationship between tannin content of sorghum grain and preharvest seed molding. Agron. J. 65:957-959.

Hay FR, Probert RJ, 1995. Seed maturity and the effects of different drying conditions on desiccation tolerance and seed longevity in foxglove (Digitalis pupurea L.). Ann. Bot. 76:639-647.

Heydecker W, Coolbear T, 1977. Seed treatments for improved performance-survey and attempted prognosis. Seed Sci. Technol. 5:353 425.

Heydecker W, Higgins J, Turner YJ, 1975. Invigoration of seeds? Seed Sci. Technol. 3:881-888.

Hoekstra FA, Crowe JH, Crowe LM, 1992. Germination and ion leakage are linked with phase transition of membrane lipids during imbibition of Typha latifolia pollen. Physiol. Plant. 84:29-34.

Horbowicz M, Oberdorf RL, 1994. Seed desiccation tolerance and storability: dependence of flatulence-producing oligosaccharides and cyclitols - review and survey. Seed Sci. Res. 4:385-405.

Hu J, Zhu ZY, Song WJ, Wang JC, Hu WM, 2005. Effects of sand priming on germination and field performance in direct-sown rice (Oryza sativa L.). Seed Sci. Technol. 33:243-248.

Jett LW, Welbaum GE, 1996. Changes in broccoli (Brassica oleracea L.) seed weight, viability and vigour during development and following drying and priming. Seed Sci. Technol. 24:127-137.

Job D, Capron I, Job C, Dacher F, Corbineau F, Côme D, 1999. Identification of germination-specific protein markers and their use in seed priming technology. In: M. Black, K.J. Bradford and J. Vasquez-Ramos (eds.) Seed biology advances and application. CABI Publishing, Cambridge, UK, pp 449-459.

Khan AA, 1991. Preplant physiological seed conditioning. Hortic. Rev. 13:131-181.

Khan AA, Peck NH, Samimy C, 1980. Seed osmoconditioning: physiological and biochemical changes. Israel J. Bot. 29:133-144.

Khan AA, Tao AL, Knypl JS, Borkowska B, Powell LE, 1978. Osmotic conditioning of seeds: physiological and biochemical changes. Acta Hortic. 83:267-278.

Kibinza S, Bazin J, Bailly C, Farrant JM, Corbineau F, El-MaaroufBouteau H, 2011. Catalase is a key enzyme in seed recovery from ageing during priming. Plant Sci. 181:309-315.

Kraak HL, Weges R. 1989. Storability of primed lettuce seed. Page 43 in Proc. 3rd Int. Workshop on Seeds, Williamsburg, VA, USA (abstr.).

Lantieri S, Kraak HL, De Vos CHR, Bino RJ, 1993. Effects of osmotic preconditioning on nuclear replication activity in seeds of pepper
(Capsicum annuum L.). Physiol. Plant. 89:433-440.

Lantieri S, Saracco F, Kraak HL, Bino RJ, 1994. The effects of priming on nuclear replication activity and germination of pepper (Capsicum annuum L.) and tomato (Lycopersicon esculentum Mill.) seeds. Seed Sci. Res. 4:81-87.

Leprince 0, Hendry GAF, McKersie BD, 1993. The mechanisms of desiccation tolerance in developing seeds. Seed Sci. Res. 3:321-246.

Mauromicale G, Cavallaro V, 1995. Effects of seed osmoconditioning on germination of tomato at different water potentials. Seed Sci. Technol. 23:393-403.

Mauromicale G, Cavallaro V, 1997. A comparative study of the effects of different compounds on priming of tomato seed germination under suboptimal temperature. Seed Sci. Technol. 25:99-408.

McDonald MB, 2000. Seed priming. In: M. Black and J.D. Bewley (eds.), Seed technology and its biological basis. Sheffield Academic Press, Sheffield, UK, pp 287-325.

McMillan WW, Wiseman BR, Burns RE, Harris HB, Greene L, 1972. Bird resistance in diverse germplasm of sorghum. Agron. J. 64:821-822.

Mexal J, Fisher JT, Osteryoung J, Reid CP, 1975. Oxygen availability in polyethylene glycol solutions and its implications in plant-water relations. Plant Physiol. 55:20-24.

Michel BE, Kauffmann MR, 1973. The Osmotic Potential of Polyethylene Glycol 6000. Plant Physiol. 51:914-916.

Nath S, Coolbear P, Hampton JG, 1991. Hydration-dehydration treatments to protect or repair stored "karamu" wheat seeds. Crop Sci. 31:822-826.

Obendorf RL, 1997. Oligosaccharides and galactosyl cyclitols in seed desiccation tolerance. Seed Sci. Res. 7:63-74.

Obendorf RL, Dickerman AM, Pflum TM, Kacalanos MA, Smith ME, 1998. Drying rate alters soluble carbohydrates, desiccation tolerance, and subsequent seedling growth of soybean (Glycine max L. Merrill) zygotic embryos during in vitro maturation. Plant Sci. 132:1-12.

Oliver AE, Crowe LM, Crowe JH, 1998. Methods for dehydration-tolerance: depression of the phase transition temperature in dry membranes and carbohydrates vitrification. Seed Sci. Res. 8:211-221.

Osborne DJ, 1983. Biochemical control of system operating in the early hours of germination. Can. J. Bot. 61:3568-3577.

Owen PL, Pill WG, 1994. Germination of osmotically primed asparagus and tomato seeds after storage up to 3 months. J. Am. Soc. Hortic. Sci. 119:636-641

Ozbingol N, Corbineau F, Groot SPC, Bino RJ, Côme D, 1999. Activation of the cell cycle in tomato (Lycopersicon esculentum Mill.) seeds during osmoconditioning as related to temperature and oxygen. Ann. Bot. 84: 245-251.

Parera CA, Cantliffe DJ, 1992. Enhanced emergence and seedling vigor in shrunken-2 sweet corn via seed disinfection and solid matrix priming. J. Am. Soc. Hortic. Sci. 117:400-403.

Parera CA, Cantliffe DJ, 1994. Presowing seed priming. Hortic. Rev. 16:109-141.

Patanè C, Cavallaro V, D’Agosta G, Cosentino SL, 2008. Plant emergence of PEG-osmoprimed seeds under suboptimal temperatures in two cultivars of sweet sorghum differing in seed tannin content. J. Agron. Crop Sci. 194:304-309.

Pill WA, Korengel TK, 1997. Seed priming advances the germination of Kentucky bluegrass (Poa pratensis L.). J. Turfgrass Manage. 2:2743.

Pill WG, 1995. Low water potential and presowing germination treatments to improve seed quality. In: S. Basra (ed.) Seed quality. Basic mechanisms and agricultural implications. Food Products Press, London, UK, pp 319-360.

Pill WG, Collins CM, Goldberger B, Gregory N, 2009. Responses of nonprimed or primed seeds of "Marketmore 76" cucumber (Cucumis sativus L.) slurry coated with Trichoderma species to planting in 
growth media infested with Pythium aphanidermatum. Sci. Hortic. 121:54-62.

Posmyk MM, Corbineau F, Vinel D, Bailly C, Côme D, 2001. Osmoconditioning reduces physiological and biochemical damage induces by chilling in soybean seeds. Physiol. Plant. 111:473-482.

Redfearn M, Osborne DJ, 1997. Effects of advancement on nucleic acids in sugarbeet (Beta vulgaris) seeds. Seed Sci. Res. 7:261-267.

Roberts EH, Ellis RH, 1989. Water and seeds survival. Ann. Bot.-London 63:39-52.

Rowse HR, 1996. Drum priming. Seed Sci. Technol. 24: 281-294.

Salehzade H, Shishvan MI, Ghiyasi M, Forouzin F, Siyahjani AA, 2009. Effect of seed priming on germination and seedling growth of wheat (Triticum aestivum L.). Res. J. Biol. Sci. 4:629-631.

Salisbury FB, Ross CW, 1985. Plant physiology, 3rd ed. Wadsworth Publishing Co., Belmont, CA, USA.

Samfield DM, Zajicek JM, Cobb BG, 1991. Rate and uniformity of herbaceous perennial seed germination and emergence as affects by priming. J. Am. Soc. Hortic. Sci. 116:10-13.

Soeda Y, Konings MCJM, Vorst 0, van Houwelingen AMML, Stoopen GM, Maliepaard CA, Kodde J, Bino RJ, Groot SPC, van der Geest AHM, 2005. Gene expression programs during Brassica oleracea seed maturation, osmopriming, and germination are indicators of progression of the germination process and the stress tolerance level. Plant Physiol. 137:354-368.

Subedi KD, Ma BL, 2005. Seed priming does not improve corn yield in a humidity temperate environmental. Agron. J. 97:211-218.

Sung FJM, Chang YH, 1993. Biochemical activities associated with priming of sweetcorn seed to improve vigor. Seed Sci. Technol. 21:97-105.

Tarquis AM, Bradford JK, 1992. Prehydration and priming treatments that advance germination also increase the rate of deterioration of lettuce seeds. J. Exp. Bot. 43:307-317.

Taylor AG, Allen PS, Bennet MA, Bradford KJ, Burris JS, Misra MK, 1998. Seed enhancements. Seed Sci. Res. 8:245-256.

Taylor AG, Beresniewicz MM, Goffinet MC, 1997. Semipermeable layer in seeds. In: R.H. Ellis, M. Black, A.J. Murdoch and T.D. Hong (eds.) Basic and applied aspects of seeds biology. Kluwer Academic Publ., Dordrecht, The Netherlands, pp 429-436.

Taylor AG, Harman GE, Nielsen PA, 1994. Biological seed treatments using Trichoderma harzianum for horticultural crops.
Horttechnology 4:105-109.

Thornton JM, Collins ARS, Powell AA, 1993. The effect of aerated hydration on DNA synthesis in embryos of Brassica oleracea L. Seed Sci. Res. 3:195-199.

Tiryaki I, Buyukcingil Y, 2009. Seed priming combined with plant hormones: influence on germination and seedling emergence of sorghum at low temperature. Seed Sci. Technol. 37:303-315.

Varier A, Vari AK, Dadlani M. 2010. The subcellular basis of seed priming. Curr. Sci. India 99:450-456.

Wahid A, Noreen A, Basra SMA, Gelani S, Farooq M, 2008. Priminginduced metabolic changes in sunflower (Helianthus annuus) achenes improve germination and seedling growth. Bot. Stud. 49:343350.

Warren JM, Bennett MA, 1997. Seed hydration using the drum priming system. Hortscience 32:1220-1221.

Warren JM, Bennett MA, 1999. Bio-osmopriming tomato (Lycopersicon esculentum Mill.) seeds for improved stand establishment. Seed Sci. Technol. 27:489-499.

Welbaum GE, Bradford KJ, 1990. Water relations of seed development and germination in muskmelon (Cucumis melo L.). IV. Characteristics of the perisperm during seed development. Plant Physiol. 92:1038-1045.

Welbaum GE, Bradford KJ, 1991a. Water relations of seed development and germination in muskmelon (Cucumis melo L.). VI. Influence of priming on germination responses to temperature and water potential during seed development. J. Exp. Bot. 42:393-399.

Welbaum GE, Bradford KJ, 1991b. Water relations of seed development and germination in muskmelon (Cucumis melo L.). VII. Influence of after-ripening and ageing on germination responses to temperature and water potential. J. Exp. Bot. 42:1137-1145.

Welbaum GE, Shen Z, Oluoch M0, Jett LM, 1998. The evolution and effects of priming vegetable seeds. Seed Technol. 20:209-235.

Wolkers WF, Bochicchio A, Selvaggi G, Hoekstra FA, 1998. Fourier transform infrared micro-spectroscopy detects changes in protein secondary structure associated with desiccation tolerance in developing maize embryos. Plant Physiol. 116:1169-1177.

Wurr D, Fellows J, 1983. The effects of the time of seedling emergence of crisp lettuce on the time of maturity and head weight at maturity. J. Hortic. Sci. Biotechnol. 58:561-566. 